\title{
Arab-Origin Students' Experiences of Learning Turkish: A Case Study
}

\author{
Esra Karakuş Tayşi \\ Correspondence: Esra Karakuş Tayşi, Kütahya Dumlupınar University, Faculty of Education, Department of Turkish \\ and Social Sciences Education, Kütahya, Turkey.
}

Received: October 20, 2018

doi:10.11114/jets.v6i12.3671
Accepted: November 5, 2018

Online Published: November 9, 2018

URL: https://doi.org/10.11114/jets.v6i12.3671

\begin{abstract}
The purpose of this study is to consider the Turkish learning situations of the 16 Arab-origin students learning Turkish at TÖMER subordinate to a state university in the Aegean region from the perspectives of both students and the teachers who teach them Turkish and investigate their language learning experiences from many perspectives. In order to achieve this goal, a qualitative research method was used. Data were collected from the participating students and lecturers through semi-structured interviews. The method of content analysis was used in the data analysis. Based on the findings obtained in the data analysis, it was concluded that the students stated that; they learnt Turkish to study at a university and because they had to live in Turkey; they had the most difficulty in the writing skill; they found the Turkish lessons difficult due to the different language structure and alphabet. On the other hand, the participating lecturers stated that; the students had difficulties in writing; they used Turkish by having conversations with Turkish native speakers and at work; the mistakes they made the most were suffix and spelling mistakes, and in order to solve these problems, they got the students to play concept games, and had lessons in different places outside the classroom by getting the students to do a lot of practice.
\end{abstract}

Keywords: Arab-origin students, teaching Turkish to foreigners

\section{Introduction}

The conflicts that have broken out as a result of political structuring in the Middle East geography in recent years have caused the people of the region to migrate especially to the neighboring countries. Due to its geographical location, Turkey is one of the leading countries under the influence of this wave of migration. According to the report by the Migration Administration subordinate to the Ministry of Interior Affairs, as of the end of 2016, there are more than 3 million Syrian migrants in a total of 81 provinces. Of these migrants, 70.364 Iraqi and 65.348 Syrian citizens have residence permits (see, the Migration Administration of the Ministry of Interior Affairs of the Turkish Republic, 2017).

Migration movement is an act of replacement. However, considering the causes and consequences, it is clearly observed that it is not a simple act and has generated comprehensive changes over the individuals and communities. Migration has two dimensions in terms of the migrants and those living in the migrated places. Both groups of people face political, economic and social problems with regards to the process of social adaptation (Sezgin \&Yolcu, 2016, p. 419). One of the emerging problems with migration, may be the most important one is the fact that the migrants do not speak the language of the country they have migrated to; it is because the social and individual needs necessitate learning the local language.

Language is the most important tool that has a significant power in shaping the opinions, attitudes and social trends enabling the interaction between people and individuals to express themselves by integrating with the society. Language constitutes the basis of meaningful communication and adaptation for individuals in the society. What individuals understand and communicate has got a lot to do with their mastery of the language spoken in that region. The individuals who migrate to a country which has a different language have to use the language of that country even to be able to meet their basic needs.

Speaking a language, in addition to the mastery of vocabulary and structures in that language, comprises being able to have verbal or written communication with the native speakers of that language by using those vocabulary and structures. Speaking a language means knowing which words and structures to use in a certain social context; that is, having communicative proficiency (İşcan, 2014, p. 4). It is possible to say that presence in a foreign country is proportionate to the proficiency level of using the target language. 
The Arabs, who migrate to Turkey wish to learn Turkish in order to complete their unfinished education, take advantage of the employment opportunities, stay in touch with the local community, enhance the quality of living etc. Research on the adaptation problems of foreign students has revealed that language learning is the basic step of this process (Zhang \& Goodson, 2011; Ercan, 2012; Kılıçlar, Sarı \& Seçilmiş, 2012; Özçetin, 2013; Brunton \& Jeffrey, 2014; Şimşir \& Dilmaç, 2018; Kardeş \& Akman, 2018). Ercan (2012, p. 19) reported that foreign students avoid communication, feel lonely and experience lack of self-confidence and cannot express their thoughts as they wish due to their lack of competence in social language skills. Zhang and Goodson (2011) concluded that language competence has a direct effect on students' socio-cultural and psychological adjustment.

As reported in the Refugees and Refugees Report (2016), one of the main problems of immigrants is language. In the report, it is stated that migrants and refugees do not even know the language they need to meet their daily needs, to go to a supermarket, to find the shelf they want and ask what they want to ask. It was concluded that Syrian students have difficulty in understanding the lessons because they do not know enough Turkish and they do not want to go to school during the education process. Similar conclusions were reached in the report on Syrian refugees and health services report (2014) prepared by the Turkish Medical Association. It has been found out that lack of competence in Turkish language leads to serious obstacles to access to public services, communication, education and social life, especially health services. Individuals interviewed said that they felt safe when they did not leave the house because they did not know the language; thus, they did not want to take their children out.

For these reasons, language teaching is included in policies and practices for migrants and refugees. Some of the information in the report published by the Migration Administration shows that language is necessary to exist in social life. In the report, it was stated that Syrians coming with an intensive wave of migration are taught Turkish in the Temporary Training Centers for Syrians by Turkish teachers 15 hours a week. It was also stated that under the coordination of the Presidency for Overseas Turks and Relative Communities University Education scholarships and Turkish Language Education supports are provided for Syrians who are in the status of temporary protection by using the resources of the country in partnership with international organizations (Turkish Republic Ministry of Interior Affairs Migration Management Directorate, 2018). As it is reported in research, it is a basic condition for the individual to learn the language of a country in order to maintain his / her life in a country where his/her mother tongue is not spoken. As a result, there has been an increased demand for the state-owned or private-sector language teaching centers. One of those institutions is the Turkish Teaching Centers (TÖMER) operating within a state university.

The purpose of the current study is to investigate the Turkish learning situations of Arab-origin students learning Turkish at TÖMER affiliated to a state university from the perspectives of both the students and the teachers teaching Turkish to them and to evaluate the problems they encounter in this process from many different perspectives. Through the detection of these problems, some contributions can be made to their solutions and to the related research in the literature.

\section{Method}

The present study is a qualitative research in the nature of a case study. A case study is qualitative approach in which a researcher collects detailed and in-depth data regarding the real life, a recent limited situation or limited multiple situations within a certain time through multiple sources of information such as interviews, observations and reports, and considers a the description of a case or the themes of a case thus investigating a current case within its own reality (Creswell, 2013, p. 97; Yıldırım \& Şimşek, 2005).

In the present study, a total of 16 Arab-origin students from different age groups learning Turkish at the Turkish Teaching Center subordinate to a state university in a province in the Aegean region were examined. Five of the students were of Iraq origin and 11 of Syrian origin. The students were placed in this region by the United Nations. The student who migrated together with their families did not have residence permits to live outside this pre-designated region. At TÖMER, students from Turkmenistan, Kazakhstan, and Kyrgyzstan learn Turkish as well. However, since the mother tongues of these students come from the same language family as Turkish, different methods are used in their teaching compared to other groups, and their learning processes proceed faster. Arabic, an inflected language in terms of structure, is a language that belongs to the Semitic arm of the Semitic language family.

In inflected languages, there are single or multi-syllables as well as suffixes. The basic characteristic of this language family is especially the change the vowel in the root undergoes during the inflection. There are never such changes in agglutinating languages like Turkish (Aksan, 1995). In terms of origin, Turkish, on the other hand, is a member of Ural-Altaic language family and an agglutinating language, a sub-group of inflected languages in terms of structure. In inflected languages, there are unchanging fixed word roots and affixes attached to these roots. The suffixes attached to the beginning or end of the word blend with the root causing a change in the meaning or function of the word. There is no prosthetic affixation in Turkish. As the suffixes are always attached to the root or the end of the body, Turkish is an 
agglutinating language (head-final) language (Korkmaz, 2003, p. 25). The fact that Arabic, the mother tongue of the Arab students, is head-first language unlike Turkish, and their alphabet is a non-Latin one, and they have different motives of learning Turkish cause these students to proceed more slowly and with difficulty in their Turkish learning experiences in comparison to other language groups. The language students included a 70-year-old general with a Ph.D. in politics; a 45-year-old high-ranking pilot who served for the air force; two merchants aged 35 who were dealt with commerce in different fields; a 33-year-old lawyer and some university students aged between 18 and 22 . Two of the students interviewed with were female and 14 male. These students took a total of 25 hours of reading, listening, writing and grammar in a week.

\subsection{The Participants}

The participants of the present study were comprised of 8 lecturers teaching at TÖMER and 16 Arab-origin students learning Turkish at this center and agreed to participate in this study. Two of the lecturers worked at the department of Turkish education and 6 at the department of Turkish language and literature. The language proficiency levels of the students were at B1 based on the graded course system designed by the Common European Framework of Reference for Languages.

\subsection{Data Collection Process}

The data were collected by the half-structured interview forms prepared for the teachers and lecturers separately. These forms were developed by the researcher and three experts were consulted for their reliability. Based on the suggestions offered by these experts, the forms were modified. Before the interviews, the students and teachers were informed about the purpose of the study and how the information would be used; the interviews with the students who agreed to take part in the study were made with them individually at times and dates when they were available in non-class hours and with the lecturers in their offices at times determined by them. The interviews that lasted between 10-35 minutes were voice-recorded with the permission of the students and lecturers. All the interviews were made by the researcher. During the interviews, the students were asked the following questions; "What are your aims in learning Turkish?; or why are you learning Turkish?; Which of the lessons you take in learning Turkish is the most difficult one for you?; Why?; What extracurricular activities are you involved in outside the language courses you take in learning Turkish?; In your daily lives, where do you use Turkish and feel the need to use Turkish?; What kind of problems do you face in learning Turkish and what do you do in order to resolve these problems?" The questions put to the teachers in the interview were; "What are your aims in teaching Turkish to your students?; What are the language skill which the students find the most difficult?; How much do your students use Turkish in their daily lives?; What kind of problems do you face in teaching Turkish to your students and what do you do in order to resolve these problems?"

\subsection{Data Analysis}

The voice-recorded interview data were transcribed and analyzed through content analysis. The responses to each and every question were coded within themselves. Based on the codes, there themes were generated. In order to ensure the reliability of the research data, the themes were presented to two different experts and their opinions were consulted; and then the data were consulted to two different experts in qualitative field and it was concluded that $90 \%$ agreement was obtained. This rate was accepted to be reliable enough for the study (Miles \& Huberman, 1994). The data were tabulated and interpreted. While direct quotations were given, the students were coded as $\mathrm{S}$ and the teachers as $\mathrm{T}$. The research report was asked to be read by two students from whom data were collected and their opinions were obtained; no correction was regarded necessary.

\section{Findings}

The opinions obtained from the interviews were collected under the main themes of "the students' opinions on their experiences of learning Turkish" and "the teachers' opinions on the students' experiences of learning Turkish". The main and sub themes based on the sequence of the questions were tabulated together with their frequencies and supported by the direct quotations.

\subsection{The Opinions of Arab-Origin Students on Their Experiences of Learning Turkish}

The opinions of Arab-origin students on their experiences of learning Turkish, their aims of learning the Turkish language, the language skill courses they have had difficulty in while learning Turkish, the kind of difficulties they have experienced, their use of Turkish outside the language classrooms, where they feel the need to use the Turkish the most, the problems they face while learning Turkish and the ways of resolving these problems were grouped under seven themes. 
Table 1. Students' opinions regarding their aims of learning Turkish

\begin{tabular}{ll}
\hline Themes & (f) \\
\hline To study at a university & 8 \\
Because of the war & 7 \\
To study their Master's Degree at a university & 1 \\
\hline
\end{tabular}

As it is seen in Table 1, the Arab-origin students stated that they wanted to study a degree at a university in Turkey; they were forced to migrate to Turkey due to the war in their country; and they learnt Turkish because they wanted to study an M.A degree in Turkey. The direct quotations from the responses of the students are as follows:

[S1: I wanted to study in Turkey because it is the nearest country to us and best country; they have very good universities here.]; [S3: To study at a university. It is very close to Syria. There is no other country; other countries do not want us.]; [S12: I learn Turkish because I want to study and live here. We were forced to migrate here, so we were forced to learn the language as well. If we do not learn the language, we cannot survive here. ]; [S11: In order to study here in Turkey; there has been a war in my country; that's why I have come here. I chose Turkey because it is Muslim country, very close my homeland. ]; [S8: We survived a war in my country; I decided to live in Kütahya. I cannot go back to my country because there has been a war over there. Everybody speaks Turkish here. We are going to work now; I can speak Turkish. That's the important thing. It is a necessity. I can speak Arabic and English; but everyone here speaks Turkish. ]; [S9: There has been an ongoing war in my country; here I am in Turkey now; life still goes on. I live here; therefore, I am learning Turkish.].

Table 2. Students' opinions regarding the courses they had difficulty in while learning Turkish

\begin{tabular}{ll}
\hline Themes & $(\mathrm{f})$ \\
\hline Writing & 12 \\
Grammar & 5 \\
Listening & 3 \\
Speaking & 1 \\
Reading & 1 \\
\hline
\end{tabular}

As it is seen in Table 2, most of the Arab-origin students stated that the language course they had the most difficulty in was the writing course. In addition to writing, they stated that they also had difficulty in grammar, listening, speaking and reading. The direct quotations from the responses of the students regarding their opinions on this theme are as follows:

[S1: It is writing. There is no problem for me in speaking and listening but writing is difficult], [S2: It is writing. When writing and grammar are combined, it gets difficult. ], [S9: I read slowly; I write slowly.]. [S4: It is listening. People speak very fast; I cannot understand them.].

Table 3. The reasons why they have difficulties in the language skill courses

\begin{tabular}{ll}
\hline Themes & (f) \\
\hline Because the language structure is different & 14 \\
Different alphabet & 13 \\
Because the person you speak with speaks very fast & 4 \\
\hline
\end{tabular}

According to the Table 3, most of the students stated that the reason why they had difficulty Turkish lessons was because of the different alphabet; because Turkish grammar rules were different from their mother tongue; and because people spoke very fast. Their opinions are as follows:

[S1: Writing is difficult because we write in Arabic. We use Arabic alphabet. Turkish alphabet is different. Turkish grammar is different difficult for us, Arabs; writing is very difficult. It is very difficult for us to pronounce the vowels. I practiced the vowels $u, e$, o by myself at home every day; it is like they are all the same. It is difficult to say which one is $\mathrm{l}$ and which one is e. English is easier because, like Arabic, there are no suffixes; the words change. There are very long words in Turkish; [S5: Grammar is difficult. Since some things are very different from our language, we do not understand much. Rules are different.], [S11: They are writing and grammar. I do not understand grammar much; it is not like Arabic grammar.], [S12: It is writing. It is because of the vowels; there is nothing more difficult. This is the most difficult part; sometimes it is difficult to speak because of the same reason. For instance, "oldu" (it happened) and 
"öldü" (s/he died); I confuse these very much. Other things are not very difficult; if we study grammar, we can manage it. At first, I had difficulty in "you" (singular) and "you" (plural). When we were learning in the beginning, we confused it and said "we love your" instead of "we love you".];[S8: I understood the dissimilation, but did not understand the accusative. When do we say "home" and "to the home", I do not know very well. May be I will learn in five years' time. You generate new words with the suffixes. Every suffix becomes a new word and it is very confusing. Bottom (alt), six (alt)), sixth (altıncl)...]; [S3: There are no vowels in Arabic, but vowel points. The vowels in Turkish are very difficult. Which are "l,e"? We learn English; " $e$ " and " $i$ " are pronounced in English. Turkish is different; so we have problems.];[S6: The sequence of sentences is reverse in Turkish; sometimes it is confusing. The verb is at the end in Turkish; it is sometimes confusing.]

Table 4. Extracurricular Turkish language-related activities

\begin{tabular}{ll}
\hline Themes & (f) \\
\hline Chatting with the Turkish friends & 8 \\
Watching Turkish soap operas & 7 \\
Watching movies & 7 \\
Reading books & 6 \\
Watching cartoons & 1 \\
Reading children's books & 1 \\
Watching political debates on TV & 1 \\
\hline
\end{tabular}

As it is illustrated in Table 4 , the Arab students used Turkish in their extracurricular activities when they chatted with their Turkish friends, watched Turkish soap operas and movies, and read Turkish books. The responses of students who shared their opinion of this theme are as follows:

[S8: I have Turkish friends and have conversations with them.]; [S5: I watch Turkish soap operas and read Turkish books.]; [S7: I watch political debates and programs on TV. It is difficult to understand them all, but they speak well; I try to understand them.]; [S11: I watch cartoons; especially in the early period of my arrival, I watched al lot of cartoons. They are easier to understand. I read children's books. ]

Table 5. Students' need to use Turkish

\begin{tabular}{ll}
\hline Themes & (f) \\
\hline At the shopping & 9 \\
At the bazaar & 8 \\
At the market & 8 \\
At work & 4 \\
At the hospital & 4 \\
At the Police & 4 \\
At bill payment center & 1
\end{tabular}

As it is observed in Table 5, the students felt the need to use Turkish at every stage of the social life.

[S12: When we went to the police station; at work. I used to work with my uncle in Istanbul; when I went to get some materials, I did not understand what they said. I tried to express what we needed, but failed to do so. When we went to the market, we would take what we wanted and go to the cash point and pay for our shopping; that's it. That was the easiest thing.]; [S8: I used to have more difficulties, but now things have been better. I never knew any Turkish words. Now I am able to chat with sale assistants and say things like "I take this; I do not want it; is there a different color of this?; how much is it? How much does it cost? so, I am able to express myself better now. ] 
Table 6. The problems students faced while learning Turkish

\begin{tabular}{ll}
\hline Themes & (f) \\
\hline The local language used in the region (accent) & 8 \\
Unable to express the problems & 7 \\
Fast speech of people & 7 \\
Figurative expressions & 4 \\
People around do not speak English & 3 \\
Use of long sentences & 3 \\
Education of the children & 3
\end{tabular}

According to the Table 6, it is clearly seen that the fact the children failed to understand the local accent used in the regions where they received education was one of the most important problems. The fact that they had difficulty in expressing the important experiences and problems they had, the difficulties they had in the figurative expressions, long sentence structures in Turkish were the other problems the students faced. The following are students' opinions on this theme in their responses:

[S3: They speak with a local accent; it is difficult to understand it; it not like when you are reading a book. They speak fast. They speak better in Istanbul.]; [S4: I come out of the dormitory, but I cannot explain why I came out.]; [S8: I have four children; they go to school here. We do their homework together, but I cannot help them. My children speak Turkish better than me. I cannot speak with their teachers; I do not understand everything they say. ]; [S9: The most important problem is at the hospital. It is very difficult to explain which part of the body is ill; what the pain is like and where the pain is. ]; [S7: This city is not a city for travel. There is no publicity of the city; no brochures. They are all available in Istanbul. There are English brochures as well. You look at the brochure, see the place and go there. There is no such thing here. You always have to speak in Turkish.]; [S12: Before we came here, the chap in Istanbul spoke before me: but he spoke very fast. I did not understand anything; I kept staring at him. At the end, I said, "please speak slowly man; I do not understand anything.]

Table 7. Ways of resolving the problems they faced

\begin{tabular}{ll}
\hline Themes & (f) \\
\hline Asking help for friends & 8 \\
Using the body language & 6 \\
Speaking English & 4 \\
\hline
\end{tabular}

Most of the students stated that they asked help from friends and used the body language (gestures) in order to resolve the problems they faced. Their opinions in their responses on this theme are as follows:

[S8: We asked for help from a friend who could speak Turkish well.]; [S13: If they did not understand us, I used the body language (gestures) to resolve the problems.]; [S9: I sometimes go to my friends asking for help to resolve my problems. Mostly I point out where it hurts. I speak English. If the doctor speaks English too, then I explain the problem in English.]

\subsection{Teachers' Opinions on the Arab-Origin Students' Experiences of Learning Turkish}

The opinions of the teachers who taught Turkish to the Arab-origin students, their aims of teaching Turkish to them, the language skill areas where students had the most difficulty in, the extent the students used Turkish in their everyday lives, and the difficulties they face in teaching Turkish and their solution suggestions to those problems were grouped as themes.

Table 8. Aims of teaching Turkish

\begin{tabular}{ll}
\hline Themes & (f) \\
\hline Enable the students to succeed in their academic careers & 7 \\
Enable them to carry on with their everyday lives & 6 \\
Help them to be acquainted with the Turkish culture & 4 \\
Enable them to produce solutions in the social life & 1 \\
\hline
\end{tabular}


As it is clearly observed in Table 8, the teachers stated that their aims in teaching Turkish to the Arab-origin students were initially to help them succeed in their academic lives; help them carry on with their social lives; help them to be acquainted with the Turkish culture and create solution to the problems they faced in their social lives. The teachers expressed their opinions on this theme as follows: T2: "Language learning is at the same time culture learning as well. When we teach Turkish, we also teach those values of Turkish cultures reflecting us", T3: "Language learning is at the same time culture learning as well. When we teach Turkish, we also teach those values of Turkish cultures reflecting us".

Table 9. The language skill areas where students has the most difficulty

\begin{tabular}{ll}
\hline Themes & (f) \\
\hline Writing & 7 \\
Grammar & 4 \\
Listening & 4 \\
Speaking & 4 \\
Reading comprehension & 3 \\
All skills & 1 \\
\hline
\end{tabular}

As far as the opinions of the participating teachers are concerned, one skill are where the students had the most difficulty was writing. Writing was followed by grammar, listening, speaking, reading comprehension, and all the skills combined. Only few teachers stated that distribution of the courses needed to differ based on proficiency levels and origin of countries and cultures. The following are teachers' opinions on the skill areas where they faced difficulties:

[T4: In general, they have difficulties in all skills. I do not think that there is one particularly prominent skill. ]; [T7: They are writing and speaking.]; [T8: They have many problems in comprehending what they listen to and read, and in expressing themselves in writing; [T6: They do not like writing at all; instead, they prefer speaking]

Table 10. Students' experiences of using Turkish in their everyday lives

\begin{tabular}{lc}
\hline Themes & (f) \\
\hline Having conversations with Turkish native speakers & 7 \\
Using Turkish at work & 3 \\
Preferring to use English & 2 \\
\hline
\end{tabular}

The teachers stated that main reason of students' use of Turkish in their everyday lives was to chat with their Turkish native speaker friends; it was followed by the reason of having to use Turkish at work since they had to work in order to earn their living. Two of the participating teachers pointed out that since English speaking students found it easier to communicate in English, they tended not to prefer to use Turkish in their everyday lives. The following are examples take from the teachers' statements:

[T6: Students learn Turkish for different reasons; some learn for their university education; some others learn to have the proficiency to able to be employed in any job. Therefore, they are able to use the language according to the social contexts outside the classroom. [T3: They do their best in order to make friends with Turkish native speakers. They arrange Turkish speaking sessions with those friends. The students speak and their native speaker friends correct them. They are involved in these activities without any external encouragement. ]

Table 11. The problems faced while teaching Turkish

\begin{tabular}{ll}
\hline Themes & (f) \\
\hline Suffixation mistakes & 7 \\
Letter mistakes & 5 \\
Reluctance to write & 5 \\
Desire to use the mother tongue (Arabic) in the classroom & 4 \\
Desire to use English in the classroom & 4 \\
Choosing the wrong word & 4 \\
Unable to read fluently & 4 \\
Pronunciation problems & 3 \\
Lesson attendance problems & 3 \\
Their misperceptions against Turkish language & 1 \\
\hline
\end{tabular}


The teachers stated that since Arabic was an pre-inflected language, the students had serious problems in applying the rules of Turkish language, and the main problems they faced were suffixes and the mistakes they made in spelling the Turkish letters. Students' reluctance to write, their desire to use Arabic or English instead of Turkish in the classroom, choosing the wrong words when they speak or write in Turkish, being unable to read fluently and trying to read syllable by syllable and their reluctance to attend the lesson were the other problems the teachers faced.

One of the most important factors enabling success in language learning is the positive attitude of the student. T3 expressed his opinion on this theme as in the following:

"Their initial perception of the Turkish language makes it more difficult for them to learn the language. They initially tend to have low self-confidence. Many migrated and settled down in Turkey long before, but never had the chance to learn Turkish. Therefore, it takes to get rid of the perception of "We have been here in Turkey for donkey's years and failed in it. How can we learn it now? When they realize that they gradually succeed, the problem disappears." Another important dimension of learning a language is the regular attendance to the lessons and not to grow away from the process of learning. Since the students are exposed to an intensive language learning program, they find it difficult to keep up with the new subjects when they have absence. T4 pointed out his opinions on this theme as follows: "Students need to be checked on their attendance regularly. Otherwise, they act as if they just let go of this subject."

The teachers' opinions on the solutions to the above-mentioned problems are illustrated in Table 12. Teachers' suggestions for solutions were as follows: prohibition of the mother tongue use in the classroom; conducting lessons in outside classroom contexts such as the garden, drama workshops and a bookshop; getting the students to drill intensively in the subjects they have studied and enable them to make comparisons with different examples; getting them to play games such as taboo and scrabble that are effective in language learning and trying different language teaching methods.

Table 12. Solution suggestions to the problems faced while teaching Turkish

\begin{tabular}{ll}
\hline Themes & (f) \\
\hline Enabling them always to speak Turkish in the classroom & 4 \\
Attention-concept games & 4 \\
Conducting lessons outside-classroom contexts & 3 \\
Getting students to drill intensively & 3 \\
Getting them to read books & 3 \\
Using different methods & 2
\end{tabular}

It is important to use the target language in language classrooms in order for the students to be able to think in that language. T6 had the following opinion on this theme: "I prohibit the students to use Arabic, their mother tongue in the classroom. It is because it inhibits the students to use his/her mother tongue and push him/herself and think in Turkish when s/he is able to express him/herself. When you prohibit the use of the mother tongue, s/he tries hard to express him/herself in Turkish and eventually succeeds together with your help. This particular situation helps the student to gain self-confidence as well." In order to improve the proficiency, getting the students to read proficiency-level appropriate books helps them to learn new words and grasp the grammar rules. T5 and T7 had the following to say: "I give students different examples using excerpts from different books." "Initially starting with the children's books, I give them proficiency-appropriate books and get the students to read them:" The teachers pointed out that they sometimes conducted their lessons outside the classroom contexts in order to make the lessons more enjoyable and effective. "T1: I have my lessons in different contexts; in a garden, at the library, at the canteen; accordingly, I help students to observe the language being used in every social context and integrate those contexts into the learning environment."; "T3: When the weather gets hot, I sometimes have my lessons outside the classroom."

\section{Conclusion and Discussion}

The aim of the present study was to examine the opinions of Arab-origin students on their Turkish learning experiences and the opinions of their teachers on the teaching experiences to this group of students. According to the data obtained from the study, it was revealed that the aims of the Arab-origin students to learn Turkish were; their desire to study at a Turkish university since they now live in Turkey; the obligation to live in Turkey having had to leave their country because of the war; and their desire to so master's degree in Turkey. Gallagher-Brett (2004) stated that reasons such as employment, education and life requirements were in the top ten out of 700 reasons for learning a language. In his study where he studied the difficulties that the Arab students experienced while learning Turkish, Alshira (2013) also found that Arab-origin students thought that Turkish was necessary for the business life and they chose Turkey for education. 
In the study done by Tok and Yigin (2013), participant students stated that they learnt Turkish for academic, economic and political reasons. Due to its strategic location, Turkey has in recent years been exposed to migration movement and one of the ensuing results of this movement is the prominence of Turkish as a foreign language. According to Payne and Almansour (2014), political reasons and social changes encouraged the learning of foreign languages. Koçer (2013) obtained similar findings.

The students stated that the lessons they had while learning Turkish were writing, followed by grammar, listening, speaking and readings skills. Writing was the last skill that the students managed to get the proficiency of. According to Özdemir (2014), writing was the indication of high proficiency of a language. Writing is one of the most difficult skills that second-language learners are expected to acquire, requiring the mastery of a variety of linguistic, cognitive, and sociocultural competencies (Barkaoui, 2007, p. 35). Balcı \& Melanlığlu (2016) stated that language became more concrete during writing and the flexibility of rules in natural discourse disappeared in writing; therefore, writing was more conservative in comparison to speaking. Previous studies emphasized that the skill that the students had the most difficulty in was writing (Büyükikiz, 2011; Açık 2008; Biçer, Çoban \& Bakır, 2014, Alshirah 2013). Gürbüz and Güleç (2016); in their study on foreign students studying in Turkey, found that they experienced the greatest difficulty in grammar rules while learning Turkish. Different from the findings of these studies, Yildiz (2015) and Yilmaz (2014) concluded that the speaking skill was more difficult. The different findings in these studies may be based on the fact that the students in those studies learnt Turkish not in Turkey, but in a country whose mother tongue was not Turkish. Therefore, they did not have any chances to speak Turkish except in the lessons. Those who learn Turkish in Turkey have to speak the language in every moment of life; therefore, their speaking skill improves faster.

The students indicated that why they experienced difficulties in Turkish lessons was the different structure of Turkish and the different alphabet; moreover, it was because the people they communicated spoke very fast. In his study with the Syrian students who were educated at the B1 level, Demirci (2015) found that derivational and inflectional systematics of Turkish caused the learners to make some pronunciation and reading mistakes. Subaş1 (2010) found that Arab students made some derivational and structural mistakes as well as pronunciation mistakes due to the lack of some sound in Arabic. These findings are compatible with the opinions of the students in our study. In his study with the Syrian refugees on their perception of Turkish, Akkaya (2013) stated that the refugees indicated with the metaphors they chose that Turkish had its own rules and emphasized that Turkish was an agglutinating language. In different studies carried out in the relevant literature, it was revealed that the students who used the Arabic alphabet sometimes did not use the letters such as "ö, ü, ş, ç, 1, ğ, p" that were available in Turkish, but not in Arabic (Karababa, 2009; Bölükbaş, 2011; Demirci, 2015; Er, Biçer \& Bozkırlı, 2012; Şengül, 2014).

Arab students used Turkish when they had conversations with their Turkish friends outside the lessons, watched the Turkish soap operas and films, read books, and watched cartoons. In the study by Biçer (2015), it was also concluded that language learners used similar methods such as asking for help from friends, reading books and magazines, watching films and TV shows. Students pointed out that they used Turkish at the market, hospital, at shopping, police station, at work etc. As these students learnt Turkish in Turkey, they were always in interaction with the society. Since they were not people limited to their education at the university, these students felt the need, outside their lessons and close network of friends, to use Turkish, for instance, to talk to the teachers of their children and their employers.

The local version of the language (accent) used in the region is the main problem that the students face while learning Turkish. In their study with immigrant university students, Sezgin and Yolcu (2016) also stated that the students learnt vocabulary in line with the mindset of the local people. The other problems students faced included their difficulty in expressing the important events they experienced, the fast speech of local people, their difficulties in figurative expressions, long sentences in Turkish, the fact that local people do not speak English and the education process of their children. In his study done with Arab students, Alshirah (2013) concluded that 42,3\% of the students had difficulties in figurative speech and idioms.

Most of the students pointed out that in order to solve the problems they faced, they asked for help from their friends, got their meaning across through body language and gestures, and resorted to other languages. In the study carried out by Biçer (2015), it was also found that the students used body language and gestures when they failed to express their meaning in Turkish and tried to get their meaning across through the languages they could speak. Kavaliauskiene (2002) states that help from peers was an important opportunity to resolve shortcomings.

One of the main reasons of the teachers' aims to teach Turkish to the Arab-origin students was to help them succeed in their academic lives. Getting them to carry on with their everyday lives and helping them to be familiarized with the Turkish culture and finding basic solutions in their social lives were the other reasons. The teachers also stated that writing was the language skill that the students had the most difficulty with. This opinion of teachers was in parallel with those of the students. The teachers stated that the students used Turkish in their everyday lives by having 
conversations with Turkish native speakers; and those already working at a job by speaking it at the workplace.

The who stated that the main problem faced by the teachers while teaching Turkish were suffixes and spelling mistakes also pointed out the problems of the desire to speak in the mother tongue in the classroom, reluctance to write, wrong choice of vocabulary, and pronunciation problems. In his study, Bölükbaş (2011) found that of the case suffixes, the ones students confused the most were accusative case and dative case suffixes; students stated that mostly they almost never used the accusative case suffix saying that unlike Turkish, the verb inflections in Arabic were done on the pronouns. In the studies carried out by Akdoğan (1993) and Güven (2007), they found that the suffix that the students had the greatest difficulty with and misused was the accusative case suffix. In his study with teachers on the teaching of case suffixes, Melanlığlu (2012) concluded that the participating students thought that the cases suffixes were like words and tried to attribute a meaning to them; they tried to find corresponding equivalents in their mother tongues or in English; and since the case suffixes had abstract structures, the students had difficulties in making them concrete. 45,7\% of the students who participated in Alshirah's (2013) study stated that they had difficulties in case suffixes. Açık (2008) explicated that the problems faced in teaching Turkish were primarily alphabet-originated emphasizing that the fact the vowels expressed in eight letters in the Latin alphabet were corresponded by 3 symbols in Arabic was the main cause of this problem.

In order to resolve this problem, the teachers stated that they tried to make sure that Turkish was always spoken in the class because getting the students to speak in the target language in the classroom would help them to think in that language. Biçer (2015) stated in his study that he expected students to speak only in Turkish in the classroom. In their study they carried out with the students studying at the French language department, Savlı and Kalafat (2014) found that as the proficiency level of the students increased, the need to use the mother tongue decreased, and the idea that the mother tongue should not be used was highlighted. They explained that their alternative suggestions for the resolution of students' problems included getting them to drill abundantly through different games, and getting them to witness the diversity of language use by having lessons in different places outside the classroom. Biçer's finding (2015) that the students liked different language activities and game activities, and Karababa and Karagül's finding (2013) that the students needed listening, video-watching and small-group discussions throughout their language learning process indeed support the findings we have obtained in this study as well.

As far as the findings obtained in this study are concerned, it is clearly seen that the opinions of the teachers and students throughout their Turkish learning processes have parallels with one another. It is also noticeably observed that the students living in Turkey for different reasons try very hard to learn the Turkish language and likewise, the teachers teach it to them. In order to enable the students to be more successful in this period, language drill and exercises that will help students to make the language they have difficulty with more concrete for them should be further provided to the learners. Students' works should be individually examined and feedback should be provided; therefore, the students should be enabled to see their own mistakes and eventually correct them. Those who teach Turkish should have the mastery of both the grammar and culture of the language; it is because the aim of language teaching is to help the learners to improve their ability to express themselves, to communicate with others and indirectly to transmit the culture of nation whose language the student learns. Language acquisition comprises a certain time period. Despite the presence of effective factors in this process, the guidance of those who teach language is crucially significant as well.

\section{References}

Açık, F. (2008). Problems confronted with teaching Turkish language for foreigners and proposal for solutions. Doğu Akdeniz University Education Faculty Department of Turkish Language Education International Turkish Education and Teaching Symposium, KKTC.

Akdoğan, G. (1993). Common errors and causes in name status and shooting in teaching Turkish as a foreign language. (Unpublished master's thesis). University of Ankara Social Sciences Institute, Ankara, Turkey.

Akkaya, A. (2013). Syrian refugees' perception of the Turkish language. Ekev Akademi Dergisi, 17(56), 179-190.

Aksan, D. (1995). Her Yönüyle Dil. Ankara: Türk dil kurumu publications.

Alshirah, M. (2013). The problemse and difficulties which Arabic students encounter in learning Turkish as a foreign language. (Unpublished master's thesis). Istanbul University Institute of Social Sciences Department of Turkish as a Foreign Language İstanbul, Turkey.

Balcı, M., \& Melanlığlu, D. (2016). Evaluating foreign students' Turkish writing skills for coherence. Akademik Araştırmalar Dergisi, 67, 115-128.

Barkaoui, K. (2007). Teaching writing to second language learners: insights from theory and research. Canada: University of Toronto. TESL Reporter, 40(1), 35-48. 
Biçer, N. (2015). Examination of learner autonomy processes in teaching Turkish to foreigners. (Unpublished doctoral dissertation).University of Erzurum Atatürk, Erzurum, Turkey.

Biçer, N., Çoban, İ., \& Bakır, S. (2014). The problems faced by the foreign students learning Turkish Atatürk university case. The Journal of International Social Research, 7(29), 125-135.

Bölükbaş, F. (2011). An evaluation of Arab students' Turkish writing skills”. Turkish Studies, 6(3), 1357-1367.

Brunton, M., \& Jeffrey, L. (2014). Identifying factors that influence the learner empowerment of international students. International Journal of Intercultural Relations, 43(B), 321-334. https://doi.org/10.1016/j.ijintrel.2014.10.003

Büyükikiz, K. K. (2011). A research on the relationship between writing skills and self efficacy perception of learners of Turkish as a foreign language. (Unpublished doctoral dissertation). Gazi University, Ankara, Turkey.

Creswell, J. W. (2007). Qualitative inquiry \& research design: choosing among five approaches. Thousand Oaks: Sage Publications.

Demirci, M. (2015). Determinations related to reading aloud skills of Syrian Turkish learning students in level b1. Turkish Studies International Periodical for the Languages, Literature and History of Turkish or Turkic, 10(7), 333-358. https://doi.org/10.7827/TurkishStudies.8149

Er, O. N., Biçer, N., \& Bozkırlı, K. Ç. (2012). Evaluation of problems encountered in Turkish teaching for foreigners in terms of related literature. Uluslararası Türkçe Edebiyat Kültür Eğitim (TEKE) Dergisi, 1(2), 51-69. https://doi.org/10.7884/teke.51

Ercan, M. S. (2012). Examinatıon of cultural adaptation problems of international students and of their expectatıons toward the solutıons of these problems. (master thesis). Başbakanlık Yurtdışı Türkler ve Akraba Topluluklar Başkanlı̆̆

Gallagher-Brett, A. (2004). Seven hundred reasons for studying languages. Languages Linguistics Area Studies.

Gürbüz, R., \& Güleç, İ. (2016). Ideas On Turkish Of Foreign Students Who Are Educating In Turkey: Example of Sakarya University. Sakarya University Journal of Education, 6(2), 141-153. https://doi.org/10.19126/suje.18712

Güven, E. (2007). A study on the analysis of the errors by foreigners in learning Turkish regarding nominal case suffixes and some suggestions to eliminate these errors. (Unpublished master's thesis). Dokuz Eylül University, İzmir, Turkey.

İşcan, A. (2014). Teaching Turkish as a foreign language. In A.Şahin (Ed.) Foreign language teaching and history of teaching Turkish as a foreign language. Ankara: PegemA Publishing.

Karababa, Z. C. (2009). Teaching Turkish as a foreign language and problems encountered. Ankara Üniversitesi Eğgitim Bilimleri Fakültesi Dergisi, 42(2), 265-277. https://doi.org/10.1501/Egifak_0000001185

Karababa, Z. C., \& Karagül, S. (2013). A needs analysis for learners of Turkish as a foreign language. Education and Science, 38(170).

Kardeş, S., \& Akman, B. (2018). Teachers' views on the education of Syrian refugees. Elementary Education Online, 17(3), 1224-1237.

Kavaliauskienë, G. (2002). Three activities to promote learner autonomy. The Internet TESL Journal, VIII(7). http://iteslj.org/Techniques/Kavaliauskiene-Autonomy/.

Kılıçlar, A., Sarı, Y., \& Seçilmiş, C. (2012). The effect of the students of Turkish world on the academic achievement of the problems they experienced: the case of tourism students. Bilig, 61, 157-172.

Koçer, Ö. (2013). The first step in curriculum development: needs and situation analysis in teaching Turkish as a foreign language. Ĕgitim ve Bilim, 38(169).

Korkmaz, Z. (2003). Türkiye Türkçesi Grameri (Şekil Bilgisi). Ankara: Türk dil kurumu publications.

Melanlığlu, D. (2012). The views of instructors that teach Turkish to foreigners on teaching case-endings: a qualitative study. Turkish Studies, 7(4), 2401-2411. Doi Number: 10.7827/TurkishStudies.4121

Migration Administration of the Ministry of Interior Affairs of the Turkish Republic (2017). Retrieved from http://www.goc.gov.tr/icerik6/ikamet-izinleri_363_378_4709_icerik

Miles, M., \& Huberman, M. (1994). Qualitative data analysis. USA: Sage Publications.

Özçetin, S. (2013). The factors that effect foreign university students social adaptation. (Unpublished master thesis). Hacettepe Üniversitesi University, Ankara, Turkey 
Özdemir, B. (2014). The effect of analytical writing and assessment method on pre-service Turkish teachers' writing skills and attitudes towards writing. (Unpublished doctoral dissertation). Gazi University, Ankara, Turkey.

Payne, M., \& Almansour, M. (2014). Foreign language planning in Saudi Arabia: beyond English. Current Issues in Language Planning, 15(3), 327-342. https://doi.org/10.1080/14664208.2014.915461

Refugees and Refugees Report (2016). Ankara: Turkey barolar birliği publications. Retrieved from http://www.madde14.org/images/8/8b/TBBMulteciRapor2016.pdf

Şavlı, F., \& Kalafat, S. (2014). Opinions of teachers and students about the use of mother tongue in foreign language classes. Turkish Studies, 9(3), 1367-1385. https://doi.org/10.7827/TurkishStudies.6086

Şengül, K. (2014). Alphabet issues in teaching Turkish as a foreign language. Uluslararası Türkçe Edebiyat Kültür Eğitim Dergisi, 3(1), 325-339.

Sezgin, S., \& Yolcu, T. (2016). Social cohesion and social acceptance process of incoming international students. Humanitas, 4(7), 417-436. https://doi.org/10.20304/husbd.14985

Şimşir, Z., \& Dilmaç, B. (2018). Problems teachers' face and solution proposals in the schools where the foreign students are educated. Elementary Education Online, 17(2), 1116-1134.

Subaşı, D. (2010). Error analysis on composition of Arabian learners of Turkish at Tömer. Dil Dergisi. 148.

Syrian Refugees And Health Services Report (2014). Ankara: Turkish medical association publications. Retrieved from http://www.ttb.org.tr/kutuphane/siginmacirpr.pdf

Tok, M., \& Yıgın, M. (2013). Foreign students reasons for learning Turkish: a case study. Journal of Language and Literature Education, 8, 132-147.

Turkish Republic Ministry of Interior Affairs Migration Management Directorate (2018). Retrieved from http://www.goc.gov.tr/files/files/2016_yiik_goc_raporu_haziran.pdf

Yıldırım, A., \& Şimşek, H. (2008). Sosyal bilimlerde nitel araştirma yöntemleri. Ankara: Seçkin publications.

Yıldız, Ö. (2015). Perceptions of students and teachers about the language skills in the context of teaching Turkish as a foreign language. International Journal of Languages' Education and Teaching, 3(1), 429-443.

Yllmaz, F. (2014). An investigation into students' Turkish language needs at Jagiellonian University in Poland. Educational Research and Reviews, 9(16), 555-561. https://doi.org/10.5897/ERR2013.1701

Zhang, J., \& Goodson, P. (2011). Predictors of international students' psychosocial adjustment to life in the United States: A systematic review. International Journal of Intercultural Relations, 35(2), 139-162. https://doi.org/10.1016/j.jijintrel.2010.11.011

\section{Copyrights}

Copyright for this article is retained by the author(s), with first publication rights granted to the journal.

This is an open-access article distributed under the terms and conditions of the Creative Commons Attribution license which permits unrestricted use, distribution, and reproduction in any medium, provided the original work is properly cited. 